Elżbieta Durys

Uniwersytet Łódzki

\title{
Joanna i Róża - subwersywny wymiar macierzyństwa a filmy pamięci narodowej
}

W kinie polskim po 1989 roku wyraźnie zaznaczyły się dwa zbliżone w wymowie nurty. Wskazując na paralele z brytyjskim kinem dziedzictwa narodowego (British heritage cinema), pierwszy z nich Ewa Mazierska określiła mianem „polskiego kina dziedzictwa narodowego” (Polish heritage cinema). W jego obrębie umieściła takie filmy jak: Ogniem i mieczem (1999, reż. Jerzy Hoffman), Pan Tadeusz (1999, reż. Andrzej Wajda), Syzyfowe prace (2000, reż. Paweł Komorowski), Przedwiośnie (2001, reż. Filip Bajon), Quo Vadis (2001, reż. Jerzy Kawalerowicz) czy Pragnienie miłości (2001, reż. Jerzy Antczak) ${ }^{1}$. Drugi nurt przez badaczy określany bywa mianem „filmów pamięci narodowej”2. Do reprezentatywnych dla niego produkcji należą: Katyń (2007, reż. Andrzej Wajda), General Nil (2009, reż. Ryszard Bugajski), Generat. Zamach na Giblartarze (2009, rė̇. Anna Jadowska, Lidka Kazen), Popiełuszko (2009, reż. Rafał Wierzyński), Joanna (2010, reż. Feliks Falk), Róża (2011, reż. Wojciech Smarzowski), 80 milionów (2011, reż. Waldemar Krzystek), W ciemnościach (2011, reż. Agnieszka Holland), Czarny czwartek. Janek Wiśniewski padt (2011, reż. Antoni Krauze), Bitwa warszawska 1920 (2011, reż Jerzy Hoffman).

Oba nurty stanowią odpowiedź na typowe dla polskiej kultury zorientowanie na przeszłość, przejawiające się uprawomocnianiem tożsamości

${ }^{1}$ Ewa Mazierska, In the Land of Noble Knights and Mute Princesses: Polish Heritage Cinema, „Historical Journal of Film, Radio and Television” 2001, vol. 21, no. 2, s. 167-182.

${ }^{2}$ Odwołuję się tutaj (i konsekwentnie w dalszej części artykułu) do nazwy zaproponowanej przez Magdalenę Nowicką oraz przyjętej dla opisu i charakterystyki tego fenomenu przez Witolda Mrozka, choć istnieją również sugestie określania tego nurtu w mniej oceniający sposób; należy do nich propozycja Marcina Adamczaka, który pisze o pierwszej i drugiej fali narodowych superprodukcji. Moja decyzja podyktowana jest przyjęciem perspektywy genderowej. Zob.: Magdalena Nowicka, Post-Katyń, „Odra” 2007, nr 11, s. 90-94; Witold Mrozek, Film pamięci narodowej. Najnowsze kino polskie $w$ dyskursie polityki historycznej, [w:] red. Tadeusz Lubelski, Maciej Stroiński, Kino polskie jako kino narodowe, ha! art, Kraków 2009, s. 295-320; Marcin Adamczak, „Katyñ” i,Generat «Nil»” a (dhugi) zmierzch paradygmatu, „Kwartalnik Filmowy” 2012, nr 77-78, s. 72-94. 
narodowej poprzez odwoływanie się do i kultywowanie dominującej narracji historycznej. Oba wpisują się w tradycję typowego dla naszego kraju kina narodowego. Filmy powstające w ich obrębie kręcone są przy relatywnie dużym nakładzie środków i określane jako superprodukcje. Na etapie produkcji i wyświetlania towarzyszy im ogromne zainteresowanie mediów, a finansowanie i promocja wspierane są przez instytucje kultury, w tym Narodowe Centrum Kultury podlegające Ministerstwu Kultury i Dziedzictwa Narodowego. Wizja świata w nich prezentowana oraz relacje pomiędzy postaciami (zwłaszcza płciami) opierają się na katolicko-narodowych wartościach, stąd duże zainteresowanie i poparcie ze strony środowisk konserwatywnych i wpisanie obu tych nurtów w dyskurs tak zwanej pamięci historycznej3.

O ile jednak filmy pierwszego z wymienionych nurtów (kina dziedzictwa narodowego) były najczęściej adaptacjami ważnych dla Polaków powieści lub poematów ${ }^{4}$, kino pamięci narodowej odwołuje się zdecydowanie do dwudziestowiecznej historii państwa i narodu. Witold Mrozek zwraca uwagę na wykorzystanie w tych filmach charakterystycznych dla polskiej kultury mitów o proweniencji romantycznej. Bliżej przywołuje i analizuje trzy z nich: ideę mesjanistyczną, idealizację postaci i ich polaryzację. Utrata państwowości i późniejsza zależność stanowiły przez dziesięciolecia naczelny dramat polskich środowisk opiniotwórczych. Niemożliwość pogodzenia się z tym faktem owocowała kolejnymi powstaniami i angażowaniem się w działalność niepodległościową. Na poziomie symbolicznym jedynym możliwym wyjaśnieniem okazało się porównanie Polski do Jezusa, a jej cierpień do jego ofiary na krzyżu za ludzkość. Stąd hasło Adama Mickiewicza „Polska Chrystusem narodów”, które stało się naczelnym hasłem nurtu mesjanistycznego w polskiej myśli polityczno-historycznej. Mrozek zwraca uwagę na mit mesjanistyczny w Katyniu i Popiełuszce ${ }^{5}$.

W filmach pamięci narodowej postaci narysowane są grubą kreską, co pozwala jednoznacznie wskazać ich postawę i wartości. Świat dzieli się na dobrych (to ci, którzy walczą lub ci, którzy są mimowolnymi ofiarami systemu) oraz złych (funkcjonariuszy systemu). Pierwsi są w większości ludźmi wierzącymi. Jeśli nie deklarują się jako praktykujący katolicy, to w sytuacjach ostatecznych, odnajdują na powrót drogę do Boga (postać porucznika Piotra Baszkowskiego [Paweł Małaszyński] w Katyniu). Nawet otwarcie zbuntowana Agnieszka (Magdalena Cielecka) pragnie za przyzwoleniem księdza wystawić bratu-ofierze katyńskiej tablicę nagrobną na cmentarzu. Mrozek zwraca uwagę, że również rabin z Generała Nila przywołuje postać Chrystusa

\footnotetext{
3 Witold Mrozek, op. cit., s. 298-303.

4 Marcin Adamczak, op. cit., s. 92 (przypis 1).

5 Witold Mrozek, op. cit., s. 303-305.
} 
i posługuje się jego działalnością jako argumentem przeciw zwątpieniu. Żadna z tych postaci nie przeżywa rozterek, cierpliwie znosząc swój los ${ }^{6}$.

W polskiej tradycji narodowej, do której odwołuje się kino pamięci narodowej, zarówno mężczyznom, jak i kobietom przypisane zostały określone role i cechy. Podczas gdy ci pierwsi winni byli być wojownikami i angażować się w walkę (konspiracyjną bądź otwartą) mającą służyć sprawie narodowej, od kobiet oczekiwano wpisania się w rolę Matki Polki. Mit ten, jak wyjaśnia Joanna Szwajcowska ${ }^{7}$, pojawił się wraz z innymi mitami narodowymi w XIX wieku w podzielonej zaborami Polsce i przetrwał aż do dnia dzisiejszego ${ }^{8}$. Składają się na niego żarliwy patriotyzm, stoicka wręcz skłonność znoszenia cierpień i gotowość poświęcenia siebie oraz rodziny na ołtarzu sprawy narodowej ${ }^{9}$.

W tekstach zamieszczonych w tomie Kobiety i duch inności Maria Janion zwraca uwagę na dwa zjawiska ściśle związane z mitem Matki Polki ${ }^{10}$. Chodzi z jednej strony o zauważanie i podkreślanie przez cudzoziemców „wyjątkowej kondycji polskich kobiet” przy oficjalnym traktowaniu ich przywódczej i organizacyjnej roli jako czegoś oczywistego, ale nieistniejącego oraz, z drugiej, o „patriotyczną e man cypację kobiet [wyróżnienie w oryginale - E.D.]" ${ }^{11}$. W czasie kiedy w Europie Zachodniej i Stanach Zjednoczonych kobiety walczyły o prawa wyborcze, chcąc na równi z mężczyznami mieć udział w możliwości wpływania na władzę, Polki niemal automatycznie zrównane zostały z mężczyznami poprzez zrównanie $\mathrm{w}$ wyrokach za zaangażowanie w działalność niepodległościową ${ }^{12}$. Interesujący jest również

\footnotetext{
${ }^{6}$ Ibidem, s. 305-307.
}

7 Joanna Szwajcowska, The Myth of Polish Mother, [w:] Ewa Mazierska, Elżbieta Ostrowska, Women in Polish Cinema, Berghahn Books, New York, Oxford 2006, s. 15-33.

${ }^{8}$ Frapujące rozważania na temat przekształceń mitu Matki Polki w kulturze współczesnej znaleźć można w tomie Pożegnanie z Matką Polką? Zob.: Renata E. Hryciuk, Elżbieta Korolczuk (red.), Pożegnanie z Matka Polką? Dyskursy, praktyki i reprezentacje macierzyństwa we wspótczesnej Polsce, Wydawnictwo Uniwersytetu Warszawskiego, Warszawa 2012.

9 Joanna Szwajcowska, op. cit., s. 19.

${ }_{10}$ Tutaj, i w dalszej części, szczególnie interesują mnie trzy teksty zamieszczone w tomie Janion: Bogini Wolności (Dlaczego rewolucja jest kobietą?) (s. 5-49), Szalona (s. 50-77) oraz Kobieta - Rycerz (s. 78-101). Zob.: Maria Janion, Kobiety i duch inności, wyd. 2, Wydawnictwo Sic!, Warszawa 2006.

${ }^{11}$ Ibidem, s. (w kolejności cytowania) 98 i 55.

12 Jak podkreśla, cytowana przez Janion, Wiktoria Śliwowska: „Na ziemiach polskich zrównanie w prawach kobiet i mężczyzn dokonało się najpierw na polu wspólnie prowadzonej walki o odzyskanie niepodległości: zrównanie to przypieczętowane zostało ukazem cesarskim zaprowadzającym w marcu 1963 roku jednakowe sądy wojskowe dla przestępców obojga płci”. Wiktoria Śliwowska, Polskie drogi do emancypacji (O udziale kobiet $w$ ruchu niepodległościowym w okresie międzypowstaniowym 1833-1856), [w:] red. Barbara Grochulska, Jerzy Skowronek, Losy Polaków $w$ XIX-XX w. Studia ofiarowane profesorowi 
mechanizm zachęcania kobiet do angażowania się w tę walkę i sprzężenie jej z emancypacją, co powołało do życia legendę kobiety-rycerza i żołnierza. Janion wskazuje tutaj - podobnie jak w przypadku mesjanizmu - na twórczość Adama Mickiewicza jako jej źródło:

Mickiewicz był autorem zarówno Śmierci pułkownika, jak i wiersza Do Matki Polki. Opiewał w nich kobiece męstwo, co miało potężne znaczenie dla ukształtowania się samoświadomości kobiet w Polsce. Tworzył też legendę ofiarnej kobiety polskiej, legendę, do której tak często potem Polki się dopasowywały w życiu. W efekcie romantycznych nakazów kobieta polska przyzwyczaiła się do dźwigania ciężarów życia rodzinnego i publicznego w cieniu i w milczeniu, byle spełniła się ofiara ${ }^{13}$.

Adam Mickiewicz aktywnie współuczestniczył w tworzeniu ideału Matki Polki, precyzyjnie określając jego rysy. Jeden z wykładów Collège de France, wygłoszony 17 czerwca 1842 roku, poświęcił „ideałowi Polki”. Maria Janion zwraca uwagę na kilka jego cech dystynktywnych. Otóż, już wówczas Mickiewicz wyodrębnił prawdziwą patriotkę, jako jej przeciwieństwo wskazując Europejki (te namiętne lub nerwowe) i „warszawskie towarzystwo”. Powiązał również ów ideał z patriarchatem („córka przywiązana do ojca, żona gotowa w ogień pójść za mężem”) oraz koniecznością poniesienia ofiary. Jak stwierdzil:

Tym to sposobem wyzwala się w Polsce kobieta; ma ona tutaj większą wolność niż gdziekolwiek indziej, jest więcej szanowana, czuje się towarzyszką mężczyzny. Ni e poprzez rozprawianie o prawach kobiet, nie przez obwieszczanie urojonych teorii zdobędą kobiety znaczenie w społeczeństwie, ale przez ofiary [podkreślenie E.D.] ${ }^{14}$.

Jakkolwiek cynicznie wydaje się pobrzmiewać ostatnie zdanie (wszak wyemancypowana bojowniczka z wyrokiem i tak nie ma żadnych praw i przywilejów, gdyż ani więzienie, ani zsyłka na Sybir nie sprzyjają afirmatywnej realizacji równościowych haseł - zarówno w jednym, jak i drugim miejscu bowiem było się pozbawionym praw obywatelskich), posługując się przykładami literackimi, Janion pokazuje siłę emancypacyjną tego przekonania i niezwykle pozytywną reakcję nań rzesz (zwłaszcza młodych) kobiet ${ }^{15}$.

Choć koturnowa, szablonowa, ograniczająca i sfunkcjonalizowana w patriarchalnym dyskursie narodowym ${ }^{16}$, figura Matki Polki niesie z sobą

Stefanowi Kieniewiczowi w osiemdziesiątą rocznicę Jego urodzin, PWN, Warszawa 1987, s. 210-247. Podaję za: Maria Janion, op. cit., s. 98.

13 Ibidem, s. 99.

${ }_{14}$ Ibidem, s. 96-97.

${ }_{15}$ Ibidem, s. 54-56.

${ }^{16}$ Matkę Polkę jako znak, figurę, mit czy fantazmat funkcjonujący w obrębie Barthesowskiej podwójnej semiozy analizuje Elżbieta Ostrowska w artykule Matki Polki i ich synowie. 
pozytywne konotacje w kulturze polskiej, zwłaszcza że przez lata służyła legitymacji obecności kobiet w sferze publicznej. W Katyniu, filmie otwierającym nurt kina pamięci narodowej, Andrzej Wajda wciąż się do niej odwołuje, konstruując opowieść, która na równi oddaje dramat i hołd uwięzionym, a następnie zamordowanym mężczyznom, jak i najpierw nieświadomym ich losów, później zaś pozbawionym możliwości mówienia prawdy o mordercach kobietom. Uwidacznia się to chociażby w postaciach generałowej Róży (Danuta Stenka) i Anny (Maja Ostaszewska). Mimo wykorzystania romantyczno-patriotycznej tradycji, twórcy kina pamięci narodowej w większości zdecydowanie odchodzą jednak od figury Matki Polki, sięgając po stereotypy lansowane przez współczesne kino polskie ${ }^{17}$. Kobiety są w tych filmach albo kuszącymi uwodzicielkami, gotowymi zdradzić swoich mężczyzn (dziennikarka w 80 milionów, sanitariuszka w Obławie), albo mazgajowatymi żonami starającymi się wszelkimi możliwymi sposobami odwieść swoich mężów od służenia wyższej sprawie (córka i żona w Generale Nilu, żony w Czarnym czwartku i 80 milionach). Jedyną czynnością, której z pasją oddają się w swoich domach jest... obieranie ziemniaków.

Postacie kobiece i sposób ich przedstawiania w superprodukcjach narodowych są istotne nie tylko ze względu na kulturotwórczą rolę stereotypów genderowych. Jak zwraca uwagę Agnieszka Graff, w polskim życiu społeczno-politycznym po roku 1989 uwidoczniło się szczególnie wyraźnie „upłciowienie narodu” polegające na konkretyzowaniu wspólnoty narodowej poprzez wykorzystanie przekonań dotyczących płci ${ }^{18}$. Szczególna rola przypada w tym procesie kształtowania tożsamości wspólnoty wyobrażonej narodu kobietom. Reasumując ustalenia badaczy powiązań płci i narodu, Graff stwierdza, że kobiety:

rzadko bywają obsadzone w funkcji podmiotu, czyli pełnoprawnego uczestnika wydarzeń (a jeśli już, to często w męskim przebraniu, dosłownym lub symbolicznym); częściej postrzega się je jako pasywne „nosicielki” wartości, które dana społeczność uważa za

Zob.: Elżbieta Ostrowska, Matki Polki i ich synowie. Kilka uwag o genezie obrazów kobiecości i męskości w kulturze polskiej, [w:] red. Małgorzata Radkiewicz, Gender: Konteksty, Rabid, Kraków 2004, s. 215-227.

${ }^{17}$ Por.: Grażyna Stachówna, Suczka, Cycofon, Faustyna i inne kobiety w polskim filmie lat dziewięćdziesiątych, [w:] red. Małgorzata Radkiewicz, Gender w humanistyce, Rabid, Kraków 2001, s. 55-63.

18 Agnieszka Graff, Pteć i naród tu i teraz. Kilka uwag o genderowym i seksualnym wymiarze współczesnego polskiego nacjonalizu, [w:] red. Elżbieta H. Oleksy, Tożsamość i obywatelstwo $w$ społeczeństwie wielokulturowym, Wydawnictwo Naukowe PWN, Warszawa 2008, s. 140-158. Artykuł (pod tytułem Nasze świętości. Cudze zboczenia) stanowi również część książki Rykoszetem (Agnieszka Graff, Rykoszetem. Rzecz o ptci, seksualności, narodzie, W.A.B., Warszawa 2008, s. 33-68). W dalszej części będę odwoływała się do edycji zamieszczonej w tomie Tożsamość i obywatelstwo.... 
kluczowe dla swej tożsamości [...]. Owo „noszenie” może przynosić kobietom poczucie dumy, jednak odbywa się pod ścisłą męską kontrolą, bo wytyczanie granic danej wspólnoty narodowej czy etnicznej dokonuje się w znacznym stopniu za pomocą reguł i wyobrażeń dotyczących seksu, płodności i kobiecej „cnoty”.

Poruszanie się w obrębie seksualności, płodności i czystości implikuje pozostanie na poziomie cielesności. W dyskursie narodowym w odniesieniu do kobiet nie ma jednak mowy o ciele prywatnym, podległym woli i decyzji (kobiecego) podmiotu. Jak pisze dalej Graff:

Fantazmatyczne kobiece ciało narodu jest nośnikiem wyobrażeń o wspólnocie, jej losach, historii i przyszłości, podczas gdy ciała kobiet realnych „przenoszą” substancję narodową w sensie biologicznym, jako matki, a także przekazują kulturę kolejnym pokoleniom. Skoro naród to kobieta, kobieta jest też w jakimś sensie narodem, jej ciało „reprezentuje” terytorium państwa, zwłaszcza w sytuacji zagrożenia ${ }^{20}$.

Wizja polskiej historii i role genderowe promowane przez kino pamięci narodowej są konserwatywne i homogeniczne. $\mathrm{Z}$ tego powodu zarówno Joanna Feliksa Falka, jak i Róża Wojciecha Smarzowskiego wyróżniają się na jego tle. Zarówno w jednym, jak i drugim filmie przywołany zostaje okres drugiej wojny światowej i (w przypadku Róży) czas tuż po niej. Niezwykle istotny jest fakt, że wojna nie zostaje pokazana z perspektywy żołnierzy i cywilów walczących o wolność kraju, ale z perspektywy zwykłych ludzi, ofiar wojennych zawirowań, którzy po prostu starają się przeżyć. Co więcej, $\mathrm{w}$ większym lub mniejszym stopniu oba filmy wykorzystują kobiecą perspektywę. Ich twórcy zdobywają się na odwagę opowiedzenia historii kobiet, zazwyczaj albo spychanej na drugi plan „prawdziwej” Historii, albo pomijanej milczeniem. Zarówno Joanna, jak i Róża (główne bohaterki filmów) poddane zostają cierpieniu i umierają w trakcie filmu. Róża dosłownie - umiera na raka w ogromnych męczarniach. Z kolei Joanna, w ostatniej scenie filmu, odchodzi w dal. Dzieje się to zimą i jest ona sama w Zachodnich Tatrach, nie pozostaje więc nic innego jak odczytanie tego gestu jako formy samobójstwa. Mimo że obie kobiety są ofiarami zdarzeń, widz staje się świadkiem również heroizmu, jakim wykazują się w trakcie trwania filmowej opowieści.

Bohaterstwo Joanny i Róży związane jest z macierzyństwem. Co jednak istotne, nie chodzi tu o zinstytucjonalizowane macierzyństwo ${ }^{21}$, ale prywatne,

${ }^{19}$ Ibidem, s. 141.

${ }^{20}$ Ibidem, s. 142.

${ }^{21}$ O zinstytucjonalizowanym macierzyństwie pisała Adrienne Rich, mając na myśli wizerunek, zachowania, sposoby myślenia i odczuwania promowane (częstwo wręcz jedyne dopuszczalne) przez kulturę patriarchalną w odniesieniu do faktu posiadania przez kobietę potomstwa. Por.: Adrienne Rich, Zrodzone z kobiety: Macierzyństwo jako doświadczenie i instytucja, przeł. Joanna Mizielińska, Wydawnictwo Sic!, Warszawa 2000. 
odgrywane niejako wbrew narodowej ideologii. Decyzja, by zaopiekować się siedmioletnią żydowską dziewczynką (zostać jej matką) w przypadku Joanny i postanowienie, by pozostać z córką w swojej małej ojczyźnie w przypadku Róży, skazuje je na wyobcowanie i potępienie ze strony sąsiadów. Mimo tego żadna z kobiet zdaje się nawet przez chwilę nie żałować podjętej decyzji i obie ponoszą ich bolesne konsekwencje. W dalszej części artykułu chciałabym się bliżej przyjrzeć zarówno subwersywnemu względem ideologii głównego nurtu kina pamięci narodowej potencjałowi obu filmów, jak również wskazać te ich elementy, które osłabiają zarysowujący się w nich wywrotowy potencjał. Owa gra subwersywne-konformistyczne szczególnie uwidacznia się w Róży, jakby Smarzowski nie mógł się do końca zdecydować, jaki chce zrobić film. Zacznę od streszczenia filmu, by w dalszej części powrócić do tej wewnętrznej niespójności.

Ciche porozumienie alianckich przywódców zawarte podczas konferencji w Teheranie i potwierdzone w 1945 roku podczas konferencji w Jałcie spowodowały znaczne zmiany terytorialne w kształcie i położeniu Polski po II wojnie światowej. Wschodnia granica przesunięta została do tzw. linii Curzona. Porozumienia aliantów zakładały kompensatę za utratę terytoriów w postaci wcześniej niemieckich obszarów (tzw. Ziemie Odzyskane). Mazury były jednym z nich. Mieszkający tam Niemcy mieli zostać przesiedleni za zachodnią granicę. Ponieważ Mazurzy postrzegani byli jako wspierający Niemców, polski komunistyczny rząd wolał, by oni również wyjechali. Mazurzy nie mogli zostać zmuszeni do wyjazdu, jednak na skutek prześladowania, braku ochrony przed bandytami, ograniczeń w dostępie do jedzenia i ziarna do zasiewu, jak również używania językowego i etnicznego kryterium przy dystrybucji dóbr, większość z nich z czasem wyjechała.

Jest rok 1945. Róża (Agata Kulesza) jest Mazurką. W przeciwieństwie do męża, który służył jako żołnierz Wehrmachtu, Róża zawsze była propolska. Jak inni Mazurzy i Niemcy, którzy zdecydowali się na pozostanie po odejściu wojsk niemieckich na początku 1945 roku, kobieta cierpiała z powodu masowych gwałtów, przemocy, grabieży i napadów dokonywanych przez radzieckich żołnierzy oraz polskich i rosyjskich bandytów. By ochronić swoją nastoletnią córkę, Róża informuje sąsiadów, że Jadwiga (Malwina Buss) została zamordowana i ukrywa ją na strychu. Sytuacja Róży ulega zmianie wraz z przybyciem Tadeusza (Marcin Dorociński).

Tadeusz jest żołnierzem Armii Krajowej. Brał udział w Powstaniu Warszawskim i ukrywa się, gdyż nie chce złożyć wymaganej przez komunistyczny rząd przysięgi wierności. Mężczyzna przypadkiem dowiaduje się, że mąż Róży nie żyje, decyduje się pójść i powiedzieć o tym kobiecie, a przybywszy na miejsce, zostaje, by pomóc jej w gospodarstwie. Z czasem Róża i Tadeusz zakochują się w sobie, udaje im się uporządkować gospodarstwo, pozbyć 
rosyjskich bandytów, którzy wciąż napadają i gwałcą Różę. Okazuje się jednak, że kobieta cierpi na raka. Na łożu śmierci wyprasza na Jadwidze i Tadeuszu, by się pobrali. Po skromnej ceremonii zaślubin Tadeusz zostaje oskarżony o zdradę stanu przez Służbę Bezpieczeństwa, uwięziony, następnie jest torturowany i skazany. Z zesłania wraca dopiero w 1956 roku zmieniony nie do poznania. Po przybyciu do wioski odkrywa, że gospodarstwo Róży zostało przejęte przez ich dawnych przyjaciół i sąsiadów, repatriantów z Wilna. Jadwiga, która przez cały ten czas czekała na męża, decyduje się z nim odejść.

Pokazując upokorzenie i cierpienia, które stały sie udziałem kobiet w trakcie wojny, Wojciech Smarzowski przełamuje silnie zakorzenione w polskiej kulturze tabu. Film zaczyna się w 1944 roku sceną, w której uczestniczy ranny Tadeusz. Mężczyzna otwiera oczy i spogląda w kierunku krzyczącej kobiety. Widzi swoją żonę, Annę (Karolina Dafne Porcari), również żołnierkę Armii Krajowej, gwałconą po kolei przez niemieckich żołnierzy. Ostatni strzela jej w tył głowy. Agnieszka Morstin, pisząc o scenach gwałtu w filmie Smarzowskiego, stwierdza, że wpisuje się on w obecny we współczesnym kinie trend epatowania widzów eksplicytną przemocą ${ }^{22}$. W tym szczególnym przypadku (jak również w odniesieniu do pozostałych scen gwałtów i cierpienia w Róży) byłabym skłonna odczytać tę scenę jako gest przywrócenia historycznych obrazów wymazanych z naszej kolektywnej pamięci; obrazów degradacji i uprzedmiotowienia, których Polacy nie chcą pamiętać, opisując czasy często obecnie określane jako „czas honoru”. Kierując swoją kamerę na kobiety, Smarzowski pokazuje, że traktowane są one jako wojenne łupy. To one również dźwigają ciężar utrzymania rodziny, gdy mężczyźni walczą. Smarzowski zwraca uwagę na ich bezsilność w obliczu bezwzględności i okrucieństwa mężczyzn z bronią. Ośmiela się nawet pokazać reakcję mężczyzn na doświadczenie kobiet. Chociaż Tadeusz jest postacią heroiczną, kiedy widzi swoją żonę gwałconą i zabijaną, mdleje. W ten sposób cała scena zdaje się bardziej koszmarem sennym niż rzeczywistym doświadczeniem. Kiedy odzyskuje przytomność, doczołguje się do ciała żony i całuje ją na pożegnanie. Ale twarz Anny jest już wówczas spokojna i piękna, jakby nie doświadczyła koszmaru. Później, już na Mazurach, mimo że Tadeusz pomaga Róży, nie jest w stanie uchronić jej przed przemocą. Wielokrotnie, gdy jest poza gospodarstwem, Wasyl (Eryk Lubos), były żołnierz sowieckiej armii, przychodzi, bije i gwałci kobietę. To Jadwiga zdobywa się na ten gest i zabija prześladowcę matki. Smarzowski eksponuje jeszcze jedną, typową dla mężczyzn postawę. Po tym jak Amelia (Kinga Preis), polska repatriantka

${ }^{22}$ Agnieszka Morstin, Mocne filmy i głębokie kompleksy. „Róża” Wojtka Smarzowskiego wobec „Jak być kochana” Wojciecha J. Hasa, „Kwartalnik Filmowy” 2012, nr 77-78, s. 201 i 204. 
z Wilna, zostaje zgwałcona, jej mąż, Władek (Jacek Braciak) załamuje się i odrzuca kobietę, powtarzając wielokrotnie „zepsuli ją, zepsuli mi moją Amelkę", choć to on sam nie zdołał ochronić jej przed napastnikami.

Oskarżycielski ton filmu zostaje jednak, jak wspomniałam, w wielu miejscach podważony. Szereg zastosowanych przez Smarzowskiego chwytów wzbudza szczególne zaniepokojenie, zważywszy na subwersywną wymowę całości. Po pierwsze, tytuł odsyła do Róży jako głównej bohaterki. W samym filmie opowiedziane jednak zostają dwie historie: ta Róży i ta Tadeusza. Po drugie, historia Tadeusza rozpoczyna i kończy film, sugerując tym samym, że to jego wątek jest ważniejszy. Po trzecie, całość skonstruowana jest w taki sposób, że wskazuje na Tadeusza jako na medium, poprzez które widzowie mają dostęp do świata przedstawionego i opowiedzianych zdarzeń. Retrospekcje, które przybliżają przeszłość Róży prezentowane są jako wspomnienia opowiadane jemu albo przez pastora, albo przez samą Mazurkę. Poza tym nie wszystkie istotne z punktu widzenia widza informacje na temat Róży ujawnione zostają od razu. To, że Jadwiga żyje ukryta na strychu domu oraz że Wasyl w dalszym ciągu nachodzi Różę, bije ją i gwałci za cichym przyzwoleniem komunistycznych władz pozostaje ukryte aż do momentu, gdy albo sama Róża zdradza to Tadeuszowi, albo Tadeusz dowiaduje się przypadkiem, wróciwszy wcześniej do domu. Narracja zatem powstrzymuje się z odsłonięciem tych faktów, wzmacniając Tadeuszową perspektywę oglądu świata.

Po czwarte, historia Tadeusza jest w znacznej mierze kompatybilna z dyskursem dotyczącym polskich mężczyzn wypracowanym na gruncie kina pamięci narodowej. W gruncie rzeczy bowiem jego losy to opowieść o dzielnym żołnierzu Armii Krajowej, który nie chciał podporządkować się władzy ludowej i musiał zapłacić za to niezwykle wysoką cenę: był więziony, torturowany i skazany na wywózkę. Kiedy w ostatniej sekwencji powraca na Mazury, by odszukać Jadwigę, jego twarz jest tak zdeformowana, że z trudem daje się go rozpoznać. Po piąte, Agnieszka Morstin zwraca uwagę na jeszcze jedną ważną kwestię w konstrukcji opowieści. W omawianym filmie Róża nie tylko konsekwentnie prezentowana jest jako ofiara (a nie na przykład jako kobieta, która od czasu do czasu bywa ofiarą), ale również pozbawiona jest własnego głosu. Jej cierpienie zostaje przedstawione, ale odebrane jest jej prawo opowiedzenia o nim ${ }^{23}$. Wreszcie, Róża jest Mazurką i jej pochodzenie etniczne zostaje w filmie zdecydowanie podkreślone. Pozwala to Smarzowskiemu z jednej strony na podważenie polskich mitów narodowych, zwłaszcza wspomnianego mitu Polski-ofiary, która jedynie cierpiała podczas wojny, nie przyczyniając się do cierpień innych. Z drugiej jednak, stanowi doskonały chwyt dystansacyjny. W końcu zarówno sowieccy żołnierze, którzy dokonują masowych gwałtów, jak i bandyci, którzy nachodzą kobietę nocą,

${ }^{23}$ Ibidem, s. 206. 
gwałcą nie Matkę Polkę, ale Matkę Mazurkę. Ten chwyt - wprowadzenie Matki Mazurki jako ofiary oraz zamiana postaci kobiecych, która dokonuje się na zakończenie (u boku Tadeusza jest najpierw Róża, a później Jadwiga), dosłownie wręcz pokazana w scenie ślubu w kościele - odsyła i każe zastanowić się nad jeszcze jednym ważnym schematem myślowym wykorzystanym przez Smarzowskiego, a emblematycznym dla tradycyjnego stylu myślenia, który sytuuje tożsamość Polaków w kulturze patriarchalnej zniewolonej przez martylologiczno-mesjanistyczne obsesje.

Odwołując się do przywołanych wcześniej przeze mnie ustaleń Agnieszki Graff $^{24}$ dotyczących roli odpodmiotowionego kobiecego ciała w konstrukcji tożsamości narodowej szczególnie w okresach konfliktów i destabilizacji, Sebastian Jagielski zwraca uwagę na powracający w polskim kinie motyw tabu związków kobiet z cudzoziemcami. W Mogile nieznanego żolnierza (1927, reż. Ryszard Ordyński), Córce generała Pankratowa (1934, reż. Mieczysław Znamierowski, Józef Lejtes), a przede wszystkim Małej Moskwie (2008, reż. Waldemar Krzystek) eksploatowany jest wątek Rosjanki „zmuszonej do wyboru między porywami serca a obowiązkiem wobec ojczyzny" [s. 71]. Sprawcą owego wewnętrznego zawirowania, które, patrząc z perspektywy nacjonalistycznej, kończy się zdradą ojczyzny i podążeniem za miłością (czyli przejściem na stronę wroga) jest Polak, dzielny powstaniec lub żołnierz, służący wiernie swojemu krajowi. Przy czym zdrada własnego kraju przedstawiana jest nie tyle jako akt naganny, ale raczej jako opowiedzenie się po stronie wyższych wartości, które $\mathrm{w}$ wyniku nieprzychylnego zbiegu historycznych okoliczności ulec musiały siłom bezdusznym i dzikim (Rosji najpierw carskiej, a później sowieckiej). W ten sposób również odtwarzany jest polski scenariusz postkolonialny ${ }^{25}$. Tezą wyjściową artykułu Jagielskiego jest bowiem stwierdzenie, że w dalszym ciągu jako naród nie możemy sobie poradzić ze swoją ambiwalentną przeszłością, która - jak to niezwykle przejmująco dowiodła Maria Janion ${ }^{26}$ - sytuowała nas z jednej strony w pozycji kraju skolonizowanego i podporządkowanego, z drugiej zaś kolonizatora podporządkowującego sobie ziemie leżące na Wschodzie. O ile pod względem geograficznym sytuacja ta nie trwała z punktu widzenia historycznego długo, o tyle mentalnie wciąż pozostajemy w jej okowach, czując się gorsi względem Zachodu i lepsi względem Wschodu.

Przywołanie ustaleń Jagielskiego pozwala dostrzec wątek filmu Smarzowskiego odsunięty na dalszy plan przez dramatyzm historii Róży i historii

24 Agnieszka Graff, op. cit.

${ }^{25}$ Sebastian Jagielski, (Melo)dramatypolskości. Naród i pleć w polskim filmie patriotycznym, [w:] red. Tadeusz Lubelski, Maciej Stroiński, Kino polskie jako kino narodowe, ha! art, Kraków 2009, s. 57-83.

${ }^{26}$ Maria Janion, Niesamowita słowiańszczyzna: Fantazmaty literatury, Wydawnictwo Literackie, Kraków 2006 (zwłaszcza rozdział Sami sobie cudzy, s. 5-46). 
Tadeusza. Chodzi o wątek Jadwigi Kwiatkowskiej, córki głównej bohaterki. Jadwiga jest nastoletnią panienką, która z niezwykłym poświęceniem ukrywana jest przez matkę na strychu przed radzieckimi żołnierzami i grasującymi po okolicy bandytami. Jako widzowie przyjmujemy założenie o silnej więzi łączącej matkę i córkę, wzmocnionej traumatycznymi przeżyciami (przemarsz wojsk, gwałty) i osamotnieniem (wykluczenie ze wspólnoty, śmierć Kwiatkowskiego, nagonka ze strony polskiej władzy ludowej). Jednakże w pierwszej scenie, w której słyszymy wreszcie głos Jadwigi wyraźnie dystansuje się ona od matki. Używa bowiem języka niemieckiego, a na reprymendę Tadeusza: „Mów po polsku. Twoja matka mówi po polsku”, buńczucznie odpowiada: „Ale mój ojciec mówił po niemiecku”, sytuując isę tym samym w opozycji do matki i reprezentowanych przez nią wartości. Stopniowo jednak córka-Niemka przechodzi na „naszą” stronę. Ważne jest przy tym dookreślenie owej „naszej” strony. Jadwiga bowiem po śmierci matki, najpierw wychodzi za Tadeusza za mąż, odcinając się od możliwości repatriacji (bycia Niemką), a następnie czeka na niego kilkanaście lat, nie wiedząc, czy ten wróci. Tadeusz zaś, jak zostało już powiedziane, utożsamiony zostaje z romantyczną tradycją walki narodowo-wyzwoleńczej, poświęceniem dla ojczyzny i wartości, które tworzą jej podwaliny. Jadźka-Niemka (początkowy gest opowiedzenia się po stronie ojca i jego języka) pod wpływem miłości (bo żadnej innej logicznej motywacji nie daje się wysnuć na podstawie wskazówek dostarczonych widzowi) przechodzi na stronę Polski reprezentowanej przez Tadeusza (tu zostaje w oczekiwaniu na niego, a później z nim odchodzi), stając się Matką Polką ( $\mathrm{z}$ - jak przystało na mit - nieskalanym ciałem).

Tym gestem, co niezwykle frapujące a niedostrzegane, Jadźka dokonuje podwójnej zdrady: zdrady ojca (Niemca) i zdrady matki (Mazurki). Przypomnieć bowiem warto, co stało za decyzją Róży najpierw o pozostaniu na Mazurach, choć obie mogły wyjechać do znacznie bardziej bezpiecznych wówczas dla nich Niemiec, a następnie za prośbą, by po jej śmierci Jadwiga i Tadeusz się pobrali. Róża, bez względu na koszty, chciała pozostać w swojej małej ojczyźnie. Gotowa była za to zapłacić każdą cenę: narazić siebie i córkę na okrucieństwo żołnierzy Armii Czerwonej, zostać kochanką dowódcy oddziału stacjonującego w jej gospodarstwie, znosić wykluczenie ze społeczności Mazurów, głód, gwałty i grabieże. Zamiast chronić swoje ciało, na planie symbolicznym chroniąc w ten sposób ciało narodowe (w tym szczególnym przypadku raczej: etniczne), Róża wolała je poświęcić, wydając je na sponiewieranie i zbezczeszczenie. Degradacja fizyczna (sińce, krótkie, wystrzępione włosy, wyciekająca z niej krew oraz toczący ją od środka nowotwór) i śmierć w niezwykłych męczarniach wydają się w tej perspektywie ceną, którą okupić musiała swój podmiotowy gest. Jadźka i owszem, podporządkowuje się decyzji o pozostaniu na Mazurach oraz wychodzi za mąż 
za Tadeusza, jednak, po latach, odchodzi wraz z nim, pozostawiając innym bez słowa ziemię matki, za którą ta zapłaciła tak ogromną cenę.

Widzom oglądającym Różę już podczas pierwszych pokazów towarzyszyła świadomość, że film Smarzowskiego rzuca wyzwanie chwalebnej wersji polskiej narodowej historii. Wydaje się jednak, że wśród filmów wykorzystujących wątek macierzyństwa palma pierwszeństwa zdecydowanie należy się Joannie Feliksa Falka. Pozostawiona bez środków do życia, tytułowa bohaterka, Joanna Kurska (Urszula Grabowska), pracuje jako kelnerka w kawiarni. Jej mąż, Zbyszek Kurski zginął po wcieleniu do armii w czasie kampanii wrześniowej w 1939 roku. Od tego czasu Joanna żyje w swego rodzaju zawieszeniu - nieświadoma sytuacji, wciąż czeka na jego powrót. Pewnego dnia w kościele znajduje żydowską dziewczynkę, której matka została schwytana podczas łapanki. Z powodu tej samej łapanki Joanna straciła pracę. Kobieta decyduje się zabrać siedmioletnią Różę (Sara Knothe) do domu i ukryć ją, niepomna ani na swoją trudną sytuację finansową, ani na karę śmierci jaka grozi za przechowywanie Żydów.

Mimo że Joanna musi samotnie dźwigać ciężar tajemnicy, ukrywając fakt przygarnięcia Róży nawet przed rodziną, początkowo wszystko wydaje się działać. $Z$ powodu denuncjacji pewnej nocy zjawiają się w jej mieszkaniu niemieccy żołnierze. Nie znajdują dziewczynki, gdyż ta umyka przed nimi na tylną klatkę schodową wejściem dla służby. Czas spędzony na wychłodzonych schodach skutkuje jednak zapaleniem płuc. Kilka dni później, niemiecki oficer, zauroczony Joanną, odwiedza ją w mieszkaniu pod pretekstem oddania pożyczonej wcześniej francuskiej książki. Zaalarmowany głośnym kaszlem, odnajduje Różę. By uchronić dziecko przed śmiercią, Joanna oferuje mu swoje ciało. Mężczyzna odbywa z nią stosunek płciowy, a następnego dnia przysyła leki i jedzenie. Przed wyjazdem do Holandii, udaje mu się dowiedzieć, że mąż Joanny zmarł na zapalenie płuc na początku wojny.

Odwiedziny niemieckiego oficera SS, choć sprowokowane przez okoliczności, nie umykają uwadze sąsiadów. Joanna po raz kolejny zostaje zadenuncjowana, tym razem przed polskim podziemiem. Nie chcąc poznać powodów, dla których kobieta zgodziła się na kontakt z niemieckim oficerem, Polski Sąd Podziemny skazuje ją na publiczne upokorzenie przez ogolenie jej głowy. Załamana Joanna znieść musi jeszcze jeden cios. Poinformowana o tym, co się stało, matka kobiety wyrzeka się jej tuż przed Wigilią Bożego Narodzenia. Ostatkiem sił Joannie udaje się znaleźć dla Róży miejsce w prowadzonym przez zakonnice sierocińcu. Po czym jedzie w góry, by po raz ostatni wejść na Wołowiec - szczyt, który był świadkiem jej szczęścia przy boku męża.

W Joannie Falk problematyzuje dwa elementy niezwykle istotne dla narodowotwórczej narracji tak zwanej polityki historycznej, na której w zdecydowanej większości opiera się kino pamięci narodowej. Pierwszym z nich jest mit Matki Polki w sensie wskazanym przez Agnieszkę Graff. Chodzi 
o wpisanie Polek w dyskurs narodowy poprzez naznaczenie ich ciał treściami symbolicznymi, a dokładniej - zawłaszczenie ich ciał przez treści utożsamiane z narodem, co skutkuje pozbawieniem podmiotowości. Drugim jest antyżydowski idiom (anti-Jewish idiom) kluczowy, jak dowodzi Joanna Beata Michlic ${ }^{27}$, dla autodefinicji narodowej Polaków.

Mitowi Matki Polki w polskiej kulturze towarzyszą inne mity wspierające romantyczny dyskurs. Historia księżniczki Wandy, która nie chciała poślubić Niemca jest jednym z nich. Legendarna córka króla Kraka, po śmierci ojca, została królową Polan. Jeden z niemieckich książąt zabiegał o jej rękę. Spotkawszy się z odmową, najechał na jej ziemie. Wanda i jej armia zdołali odeprzeć wroga. Chcąc jednak uniknąć kolejnych najazdów, Wanda skoczyła ze skarpy do Wisły, popełniając samobójstwo. Joanna ze swoimi niebieskimi oczami, pełnymi ustami i policzkami, bujnymi włosami blond podpiętymi w dyskretny kok, znajomością języka francuskiego, oczytaniem oraz umiejętnością gry na pianinie stanowi doskonałe uosobienie polskiej szlachcianki, „panienki ze dworu”, która, z powodu dziewiętnastowiecznych przemian społeczno-politycznych, zasiliła szeregi inteligencji. Wierna mężowi i z oddaniem czekająca na jego powrót uosabia Matkę Polkę w jej romantycznym wymiarze. Postawiona w sytuacji królowej Wandy, łamie jednak zasady i postępuje wbrew kulturowym oczekiwaniom. Zabiera do domu i z oddaniem opiekuje się żydowską dziewczynką. Kiedy zaś Róży grozi śmierć, Joanna bez wahania oddaje się niemieckiemu oficerowi, mając nadzieję, że ofiara z jej ciała uratuje dziecko. Nie robi tego dla swojego dziecka, ani dla dziecka-Polaka. Robi to dla żydowskiego dziecka, którego obecność musi ukrywać przed rodziną, przyjaciółmi i znajomymi, gdyż relacja między nimi nie jest akceptowana.

Feliks Falk ukazuje krok po kroku proces stopniowego wykluczania kobiety z patriarchalnego społeczeństwa, gdy ta nie przestrzega ściśle określonych zasad wyznaczonych dla jej płci i przełamuje stereotypy. Co więcej, Joanna od początku do końca jest sama - nikt nie wie o jej rozterkach i powodach podejmowanych decyzji. Za samodzielne podjęcie decyzji i nietrzymanie się reguł ani jednej, ani drugiej strony, Joanna zostaje napiętnowana i wykluczona ze społeczeństwa, co równoznaczne było wówczas dla kobiety w jej sytuacji ze śmiercią. Przemysław Kaniecki podkreśla podobieństwa pomiędzy Joanną Kurską a Joanną D’Arc, które odnaleźć można w filmie Falka. Obie są osamotnione w swojej decyzji, obie muszą wystąpić poza społeczeństwo, obie uderzają w system stworzony przez mężczyzn i obie zostają za to surowo ukarane. Jednak, podczas gdy pamięć o Dziewicy Orleańskiej została zachowana i po latach uznana ona została za katolicką świętą, filmowa Joanna niesłusznie osądzona i skazana, rozpływa się w mrokach

${ }^{27}$ Zob.: Joanna Beata Michlic, Poland's Threatening Other. The Image of the Jew from 1880 to the Present, University of Nebraska Press, Lincoln and London 2006. 
historii i nawet jej własna rodzina nie chce o niej pamiętaće ${ }^{28}$. Jak wiele innych kobiet, które ośmieliły się rzucić wyzwanie patriarchatowi.

W Korzeniach totalitaryzmu Hannah Arendt podkreśla, że najtrudniejszą rzeczą dla osób umieszczonych w łagrach i lagrach nie był ból, głód i ciężka praca. Znacznie gorszą był trzy etapowy proces deprywacji oznak indywidualności i prawa do pamięci o nich. Więźniowie najpierw pozbawiani byli swoich rzeczy osobistych, następnie goleni, ubierani w takie same ubrania i oznakowywani numerami. Posiadanie członka rodziny w Gułagu w sowieckiej Rosji stanowiło zagrożenie dla całej rodziny, z kolei w niemieckich obozach zagłady mordowano, w przypadku Żydów czy Romów, całe rodziny, pamięć po tych ludziach również miała zostać wymazana ${ }^{29}$. Nie mając świadomości pomyłki ze strony podziemnego sądu, rodzina Joanny nie chce jej pamiętać. Na ironię zakrawa fakt, że jedynymi osobami, które przechowają o niej pamięć, będą żydowska dziewczynka (jeśli przeżyje wojnę) i niemiecki oficer - przedstawiciele dwóch grup, względem których reprezentanci polskich środowisk nacjonalistycznych w sposób negatywny budują polską tożsamośćc ${ }^{30}$. Zauroczony Joanną żołnierz, podczas pożegnania z nią przed przeniesieniem do Holandii, obiecuje: „Nigdy pani nie zapomnę”.

Joanna Beata Michlic zwraca uwagę na niezwykłą rolę antyżydowskiego idiomu dla konstrukcji tożsamości w polskiej narracji narodowej. Podkreśla przy tym jego trwałość. Ukształtowany ostatecznie w latach osiemdziesiątych XIX wieku, główne za sprawą działaczy związanych z Narodową Demokracją, którzy „wprowadzili antyżydowskie obrazy i stereotypy do dyskursu narodowej polityki" [s. 1] ${ }^{31}$, przetrwał, jak twierdzi badaczka, do dziś, dopasowując się do zmiennych okoliczności. Okazał się na tyle nośny, że wciąż jest wykorzystywany, mimo że obecnie w Polsce szacunkowo mieszka pomiędzy 5 a 20 tysięcy osób żydowskiego pochodzenia ${ }^{32}$. Jak pisze Michlic:

Podstawą, na której ufundowany jest etno-nacjonalistyczny [33 - E.D.] sposób przedstawiania Żyda jest pojęcie Żyda jako innego, którego cechy i społeczna aktywność stoją

${ }_{28}$ Przemysław Kaniecki, „Joanna” en face. O filmie Feliksa Falka, „Kwartalnik Filmowy” 2012, nr 77-78, s. 160-163.

${ }^{29}$ Hannah Arendt, Korzenie totalitaryzmu, przeł. Mariola Szawiel, Daniel Grinberg, Niezależna Oficyna Wydawnicza, Warszawa 1993, s. 471-493 (zwł. 487-489).

${ }^{30}$ Agnieszka Graff, op. cit.

${ }^{31}$ Tam, gdzie nie zaznaczono inaczej, cytaty ze źródeł obcojęzycznych podaję w tłumaczeniu własnym.

${ }^{32}$ Joanna Beata Michlic, op. cit., s. 6. W książce Rykoszetem Agnieszka Graff dowodzi, w jaki sposób w retoryce etnonacjonalistycznej doszło do zrównania homoseksualisty z Żydem. Por.: Agnieszka Graff, Gej, czyli Żyd... i co dalej?, [w:] eadem, Rykoszetem. Rzecz o ptci, seksualności, narodzie, W.A.B., Warszawa 2008, s. 110-142.

33 Michlic wykorzystuje w swojej książce rozróżnienie przyjęte wśród badaczy amerykańskich na nacjonalizm obywatelski (civic nationalizm) i etnonacjonalizm (ethno-nationalism). Ten pierwszy charakteryzuje się otwartością i inkluzywnym podejściem do tożsamości 
w opozycji do cech i społecznej aktywności etnicznych Polaków. Dzięki takiemu postawieniu sprawy działania i cechy Żydów traktowane są jako antagonistyczne względem politycznego, społecznego, ekonomicznego i kulturowego (religijnego) samoodczucia [well-being] etnicznych Polaków; z tego względu Żydzi i Polacy nie są kompatybilni [s. 16].

Michlic zwraca uwagę na paradoks wynikający z przyjęcia takiego założenia: „Ujęcie to może być postrzegane jako judeocentryczne ponieważ definiuje polskość jako tożsamość stojącą w opozycji do żydowskości: «Polak jest tym, kim nie jest Żyd»" [s. 16].

Można powiedzieć, że przygarniając i poświęcając się dla żydowskiego dziecka, Joanna odwraca gest Jadźki Kwiatkowskiej, poprzez który włączona została do etnonacjonalistycznie rozumianej polskiej wspólnoty. W przypadku Joanny wyłączenie ma charakter stopniowy i dokonuje się etapami. Zaopiekowanie się dziewczynką prowadzi do odsunięcia w cień tego, co dotychczas w całości wypełniało życie Joanny - myśli o zaginionym mężu-żołnierzu. Zastępując „syna ojczyzny” „córką”, Joanna sprzeniewierza się patriarchatowi, nakazującemu synów wynosić ponad córki. Ten gest zostaje tym bardziej uwypuklony, że skontrastowany z gestem odwrotnym - wyrzeczenia się Joanny przez jej matkę w imię (w planie oficjalnym) patriotyzmu. Jest to na tyle niewyobrażalne w naszej kulturze, że jeden z krytyków posunął się nawet do próby racjonalizacji i stwierdzenia, że gest zaopiekowania się dziewczynką stanowi w pewnym stopniu wyraz magicznego myślenia opartego na ekwiwalencji metaforycznej ze strony kobiety pragnącej ponad wszystko powrotu męża. Jak pisze: „Joanna uwierzyła w pewnej chwili, że ratując Różę, wyjedna także od losu ratunek dla męża [...]”34, pozbawiona tej wiary przestała walczyć o siebie (sic!).

Następnie zaś Joanna, w imię obudzonego w sobie i tak zmitologizowanego w kulturze patriarchalnej macierzyństwa dokonuje zdrady narodowego ciała, którego stanowi, jak wcześniej pisałam, emblematyczną wręcz personifikację. Swoje ciało Matki Polki in spe oddaje Niemcowi dla ratowania żydowskiego dziecka, czyli reprezentanta narodu, jak to ujęła Joanna Michlic, będącego w etnonacjonalistycznym polskim dyskursie „przerażającym Innym" (threatening Other) ${ }^{35}$. Ów gest odrzucenia syna dla córki, a następnie etnonacjonalistycznie rozumianej ojczyzny dla małej Żydówki stanowi o przełomowości Joanny. Anita Piotrowska w swojej niezwykle

narodowej. Ten drugi raczej zawęża rozumienie narodu i bazuje na genealogicznym określaniu tożsamości narodowej.

34 Piotr Śmiałkowski, Joanna, „Kino” 2010, nr 12, s. 73.

35 Ten gest również spotkał się z racjonalizacją ze strony krytyków, choć na nieco innym poziomie. Pisali oni o niezwykłym aktorstwie (i seksapilu) Urszuli Grabowskiej, „potrafiącej uratować cały ten film”, zarzucając Falkowi błąd obsadowy w przypadku Sary Knothe. Zob. chociażby: Jacek Rakowiecki, Tragedia i wzruszenie, „Film” 2010, nr 11, s. 83. 
przenikliwej recenzji z filmu Falka zwraca uwagę na jedną z ostatnich jego scen, która, potraktowana metaforycznie, puentuje ową przełomowość, stanowiąc „,samodzielny element znaczenia”. Piotrowska pisze: „Jest zresztą coś zuchwałego w tej przekornej polskiej szopce bożonarodzeniowej, stworzonej przez Falka w filmie: leżąca w barłogu młoda kobieta, odrzucona przez wszystkich, i żydowskie dziecko, dla którego nie ma miejsca w żadnej gospodzie" 36 .

Pisząc o kinie hollywoodzkim w kontekście jego podporządkowania dominującej ideologii, Barbara Klinger stwierdza, że nawet w jego obrębie powstają filmy „zbuntowane”: „Te teksty, choć twardo zakorzenione w systemie, manifestują [display] szereg cech uznawanych przez krytyków za sprzeczne z konwencjami rządzącymi «typowym» klasycznym tekstem" ${ }^{37}$. Określane jako „progresywne” lub „subwersywne” ${ }^{88}$, teksty te, mimo że zarówno w formie, jak i treści wpisują się na pozór w dominującą ideologię, to albo robią to zbyt ostentacyjnie, albo zawierają pewne „pęknięcia” 39 . Najczęściej wykorzystywanymi do tego elementami są „pesymistyczny obraz świata", szczególne tematy, elementy formy narracyjnej, styl wizualny i postacie. Umieszczenie w centrum opowiadanej historii kobiety, macierzyństwa oraz Innego - jak wskazują przykłady Joanny i Róży - niesie z sobą potencjał rozsadzenia narodowotwórczej narracji tzw. polityki historycznej ${ }^{40}$. Stąd może niechęć twórców do sięgania po te historie i wyjaśnienie, dlaczego filmy o takich postaciach, jak Anna Walentynowicz czy Irena Sendlerowa zrobili cudzoziemcy ${ }^{41}$.

${ }^{36}$ Anita Piotrowska, Śpóźnione rekolekcje, „Tygodnik Powszechny” 12 grudnia 2010, nr 50, s. 35 .

37 Barbara Klinger, „Cinema/Ideology/Criticism” Revised: The Progressive Genre, [w:] ed. Barry Keith Grant, Film Genre Reader III, University of Texas Press, Austin 2005, s. 75.

${ }^{38}$ Klinger zwraca uwagę na fakt, że krytyka ideologiczna skupiła się w swojej dominującej części na filmach hollywoodzkich reprezentujących kino gatunków, a w szczególności takie formy, jak: ,film noir, kino kobiece [the woman's film - E.D.], melodramaty rodzinne lat czterdziestych i pięćdziesiątych, horror lat siedemdziesiątych oraz kino exploitation i klasy B”. Por.: Barbara Klinger, op. cit., s. 81 .

39 Klinger odnosi się do typologii Jean-Luc Comolliego i Jeana Narboniego, wskazując na grupę pierwszą i piątą z wyróżnionych przez nich tekstów. Por.: Barbara Klinger, op. cit., s. 77-78; Jean-Luc Comolli, Jean Narboni, Cinema/Ideology/Criticism, [w:] eds. Leo Braudy, Marshall Cohen, Film Theory and Criticism, 6th edition, Oxford University Press, Oxford 2004, s. 812-819.

${ }^{40} \mathrm{O}$ subwersywnym potencjale spojrzenia na historię przez pryzmat kobiet pisała Katarzyna Taras. Zob.: Katarzyna Taras, Historia i kobiety, „Kino” 2010, nr 12, s. 13-16.

${ }^{41}$ Mam na myśli Strajk (2006, reż. Volker Schlöndorff, prod. Niemcy, Polska) i Dzieci Ireny Sendlerowej (2009, reż. John Kent Harrison, prod. USA). 


\section{BIBLIOGRAFIA}

Adamczak Marcin, „Katyń” i „Generat «Nil»” a (dtugi) zmierzch paradygmatu, „Kwartalnik Filmowy" 2012, nr 77-78.

Arendt Hannah, Korzenie totalitaryzmu, przeł. Mariola Szawiel, Daniel Grinberg, Niezależna Oficyna Wydawnicza, Warszawa 1993.

Comolli Jean-Luc, Jean Narboni, Cinema/Ideology/Criticism, [w:] eds. Leo Braudy, Marshall Cohen, Film Theory and Criticism, 6th edition, Oxford University Press, Oxford 2004.

Graff Agnieszka, Pteć i naród tu i teraz. Kilka uwag o genderowym i seksualnym wymiarze współczesnego polskiego nacjonalizu, [w:] red. Elżbieta H. Oleksy, Tożsamość i obywatelstwo w społeczeństwie wielokulturowym, Wydawnictwo Naukowe PWN, Warszawa 2008

Graff Agnieszka, Rykoszetem. Rzecz o ptci, seksualności, narodzie, W.A.B., Warszawa 2008. Hryciuk Renata E., Elżbieta Korolczuk (red.), Pożegnanie z Matką Polką? Dyskursy, praktyki i reprezentacje macierzyństwa we wspótczesnej Polsce, Wydawnictwo Uniwersytetu Warszawskiego, Warszawa 2012.

Jagielski Sebastian, (Melo)dramatypolskości. Naród i płeć w polskim filmie patriotycznym, [w:] red. Tadeusz Lubelski, Maciej Stroiński, Kino polskie jako kino narodowe, ha!art, Kraków 2009.

Janion Maria, Kobiety i duch inności, wyd. 2, Wydawnictwo Sic!, Warszawa 2006.

Janion Maria, Niesamowita stowiańszczyzna: Fantazmaty literatury, Wydawnictwo Literackie, Kraków 2006.

Kaniecki Przemysław, „Joanna” en face. O filmie Feliksa Falka, „Kwartalnik Filmowy” 2012, nr 77-78.

Klinger Barbara, „Cinema/Ideology/Criticism” Revised: The Progressive Genre, [w:] ed. Barry Keith Grant, Film Genre Reader III, University of Texas Press, Austin 2005.

Mazierska Ewa, In the Land of Noble Knights and Mute Princesses: Polish Heritage Cinema, „Historical Journal of Film, Radio and Television” 2001, vol. 21, no. 2.

Michlic Joanna Beata, Poland's Threatening Other. The Image of the Jew from 1880 to the Present, University of Nebraska Press, Lincoln and London 2006.

Morstin Agnieszka, Mocne filmy i gtębokie kompleksy. „Róża” Wojtka Smarzowskiego wobec „Jak być kochana” Wojciecha J. Hasa, „Kwartalnik Filmowy” 2012, nr 77-78.

Mrozek Witold, Film pamięci narodowej. Najnowsze kino polskie $w$ dyskursie polityki historycznej, [w:] red. Tadeusz Lubelski, Maciej Stroiński, Kino polskie jako kino narodowe, ha! art, Kraków 2009.

Nowicka Magdalena, Post-Katyń, „Odra” 2007, nr 11.

Ostrowska Elżbieta, Matki Polki i ich synowie. Kilka uwag o genezie obrazów kobiecości i męskości w kulturze polskiej, [w:] red. Małgorzata Radkiewicz, Gender: Konteksty, Rabid, Kraków 2004.

Piotrowska Anita, Śpóźnione rekolekcje, „Tygodnik Powszechny” 12 grudnia 2010, nr 50.

Rakowiecki Jacek, Tragedia i wzruszenie, „Film” 2010, nr 11.

Rich Adrienne, Zrodzone z kobiety: Macierzyństwo jako doświadczenie i instytucja, przeł. Joanna Mizielińska, Wydawnictwo Sic!, Warszawa 2000.

Śliwowska Wiktoria, Polskie drogi do emancypacji (O udziale kobiet $w$ ruchu niepodlegtościowym w okresie międzypowstaniowym 1833-1856), [w:] red. Barbara Grochulska, 
Jerzy Skowronek, Losy Polaków w XIX-XX w. Studia ofiarowane profesorowi Stefanowi Kieniewiczowi w osiemdziesiąta rocznice Jego urodzin, PWN, Warszawa 1987. Śmiałkowski Piotr, Joanna, „Kino” 2010, nr 12.

Stachówna Grażyna, Suczka, Cycofon, Faustyna i inne kobiety $w$ polskim filmie lat dziewięćdziesiątych, [w:] red. Małgorzata Radkiewicz, Gender w humanistyce, Rabid, Kraków 2001.

Szwajcowska Joanna, The Myth of Polish Mother, [w:] Ewa Mazierska, Elżbieta Ostrowska, Women in Polish Cinema, Berghahn Books, New York, Oxford 2006.

Taras Katarzyna, Historia i kobiety, „Kino” 2010, nr 12. 